\title{
Novel substituted oxadiazole - piperazine derivatives as potential MAO inhibitors: Design, synthesis, in vitro and in silico studies
}

\author{
Harun USLU 1 * (D), Begüm Nurpelin SAĞLIK 2,3 (D), Derya OSMANIYYE 2,3 (D), Kadriye BENKLI 4 (D) \\ 1 Department of Medical Services and Techniques, Vocational School of Health Services, Firat University, 23119, \\ Elazi $\breve{g}$, Turkey \\ 2 Department of Pharmaceutical Chemistry, Faculty of Pharmacy, Anadolu University, 26470, Eskişehir, Turkey \\ 3 Doping and Narcotic Compounds Analysis Laboratory, Faculty of Pharmacy, Anadolu University, 26470, Eskişehir, \\ Turkey \\ 4 Badakbas Pharmacy, Altintepe Street Koknarli 6/C Maltepe, 34840, Istanbul, Turkey \\ * Corresponding Author. E-mail: huslu@firat.edu.tr (H.U.); Tel. +90-424-237 0000.
}

Received: 16 August 2021 / Revised: 21 September 2021 / Accepted: 18 November 2021

\begin{abstract}
Recent studies have shown that there are many piperazine and oxadiazole derivatives with MAO-A and/or MAO-B inhibitory activity. For this reason in our recent study, a new compound series of oxadiazole piperazine derivatives (4a-e) were designed, synthesized, characterized and screened their $h$ MAOs inhibitory activities. When the in silico studies were examined, it was seen that the pharmacokinetic properties and interactions with the receptor of synthesized compounds were suitable. Compound 4e, with a $\mathrm{NO}_{2}$ group on the 4-position of the phenyl ring, found showing significant MAO-A inhibitory activity. Compound 4e, was the most effective agent against MAOA enzyme with $\mathrm{IC}_{50}$ value of $0.116 \pm 0.004 \mu \mathrm{M}$. The newly synthesized oxadiazole - piperazine derivatives appears to be supported studies to design MAO inhibitors to obtain more suitable drugs, against diseases such as depression and anxiety due to MAO-A.
\end{abstract}

KEYWORDS: hMAOs inhibition ; oxadiazole ; piperazine ; ADME ; molecular docking.

\section{INTRODUCTION}

Monoamine oxidases liable for the oxidative deamination of dietary amines and neurotransmitters carry the flavin adenine dinucleotide (FAD) coenzyme [1]. There are two isoforms of MAO enzymes, MAO-A and MAO-B, which act as a catalytic agent in the oxidative deamination of various monoamines such as dopamine, serotonin, histamine, noradrenaline and adrenaline $[2,3]$. Because MAOs play an significant role in the metabolism of certain neurotransmitters, there is pharmacological interest in MAO inhibitors as a result of their potential to be beneficial in the treatment of psychiatric and neurological diseases [4].

Unlike MAO-B, MAO-A does not increase with age, leading to the assumption that a completely independent mechanism regulates the expression of the two enzymatic isoforms [5]. MAO-A selective inhibitors can be used as antidepressants, while MAO-B selective inhibitors can be used to cure Parkinson's Disease (PD) and Alzheimer's Disease (AD) which neurodegenerative diseases [6]. The most common neurodegenerative diseases affecting the elderly population worldwide are stated as AD and PD. AD characterized by loss of important mental functions and memory, while PD is characterized by progressive loss of muscle control [7-9].

Compounds containing oxadiazole scaffold have become promising in recent years because they show very wide biological activity such as $A D$ activity [10-13]. There are compounds with antianxietyantidepressant effects such as Buspirone containing the piperazine structure approved for clinical use, and MAO activity studies on piperazine derivative compounds are still up-to-date [14-16]. Although there are many different classes of antidepressants in use, they have side effects and clinical limitations. Therefore, it is clear that there is a need for the development of effective and safer drugs in this area $[17,18]$.

How to cite this article: Uslu H, Sağlık BN, Osmaniye D, Benkli K. Novel substituted oxadiazole - piperazine derivatives as potential MAO inhibitors: Design, synthesis, in vitro and in silico studies. J Res Pharm. 2022; 26(1): 20-27. 
In this study, we explain the synthesis, in vitro MAO inhibition evaluation and molecular docking of a new series (4a-e) derived from 4-methoxyphenylpiperazine and substituted 1,3,4-oxadiazole-5-thiol. It is aimed to develop new compounds that we thought may be useful in the treatment of MAO-related diseases, and the relationship between MAO inhibitory activities and their structural properties has been tried to be revealed.

\section{RESULTS AND DISCUSSIONS}

\subsection{Chemistry}

In this study, we synthesized Oxadiazole - Piperazine derivatives (4a-e) in four steps. The synthetic route of the synthesized target compounds was described in Figure 1. Ethyl 2-(4-(4-methoxyphenyl)piperazin1-yl)acetate (1) was synthesized by the reactions of 1-(4-methoxyphenyl)piperazin and ethyl 2-chloroacetate. 2-(4-(4-methoxyphenyl)piperazin-1-yl)aceto hydrazide (2) was synthesized by the reactions of Compound 1 and excess of hydrazine hydrate. 5-[(4-(4-methoxyphenyl)piperazin-1-yl)-1-yl)methyl]-1,3,4-oxadiazole-2thiol (3) was synthesized by the reaction of Compound 2 and potassium hydroxide and then carbon disulfide. Compound 3 and the some 2-bromoacetophenone derivatives were then reacted in order to obtain the target compounds 4a-e. The chemical structures of the all compounds (4a-e) were confirmed by ${ }^{1} \mathrm{H}-\mathrm{NMR},{ }^{13} \mathrm{C}-\mathrm{NMR}$, HRMS. In the ${ }^{1} \mathrm{H}-\mathrm{NMR}$ spectra, all aromatic and aliphatic protons were observed in agreement with the predicted areas. In the ${ }^{1} \mathrm{H}-\mathrm{NMR}$ spectra, we clearly observed the presence of $\mathrm{N}-\mathrm{CH}_{2}$ and $\mathrm{S}-\mathrm{CH}_{2}$ protons at 3.833.84 and 5.09-5.17 ppm, respectively. In the ${ }^{13} \mathrm{C}-\mathrm{NMR}$ spectra, the carbons of the piperazine and oxadiazole rings were recorded between $51.30-52.51 \mathrm{ppm}$ and $163.85-165.25 \mathrm{ppm}$, respectively. $\mathrm{M}^{+1}$ peaks in HRMS spectra agreed well with the calculated molecular weight of the all compounds.

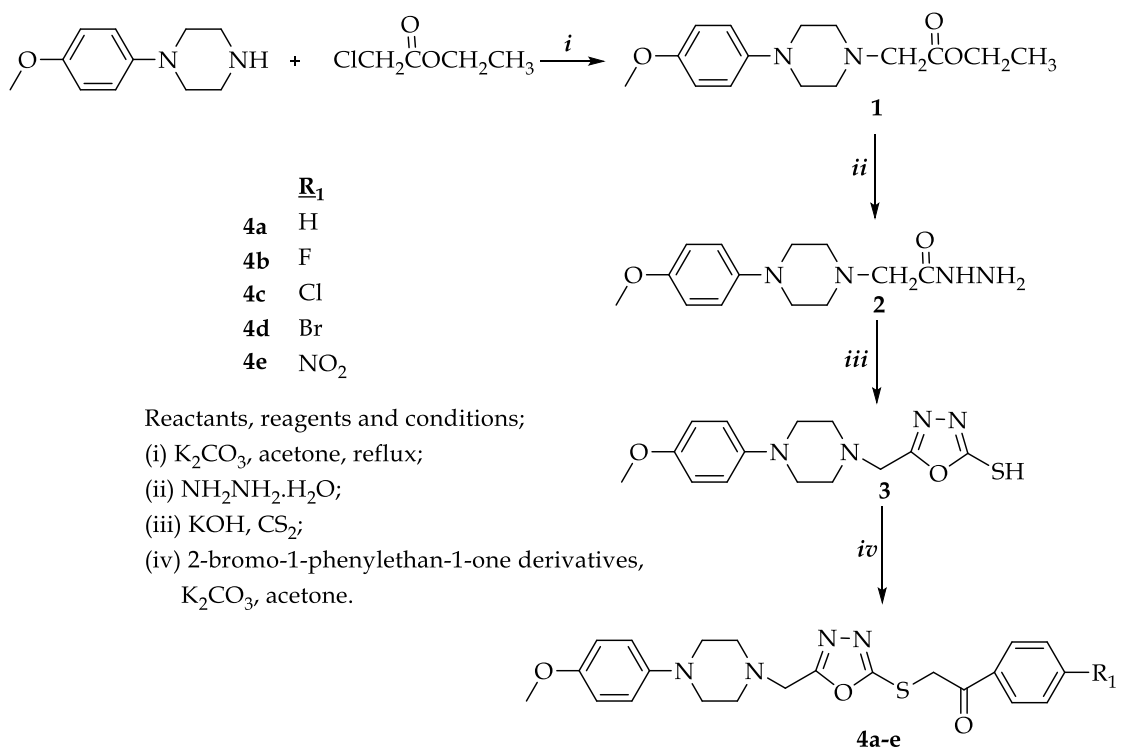

Figure 1. Synthetic pathway and the substituents for the compounds 4a-e.

\subsection{In vitro MAO inhibition}

The in vitro fluorometric method previously described by our research group was used to evaluate the MAO inhibitory potencies of the synthesized compounds [19-24]. While MAO inhibitions of all compounds and reference drugs were given in Table 1, the $\mathrm{IC}_{50}$ value of the most effective Compound $4 \mathbf{e}$ and Moclobemide, whose solutions were prepared by serial dilution, was calculated against MAO-A in Table 2.

Compound $4 \mathbf{e}$ showed a significant inhibitory potency on the MAO-A enzyme at concentration of $10^{-3}$ $\mathrm{M}$ and $10^{-4} \mathrm{M}$ but none of the synthesized compounds exhibited significant MAO-B enzyme inhibition. Compound $4 \mathbf{e}$ was determined as the most active derivative in the series with $\mathrm{IC}_{50}$ value of $0.116 \pm 0.004 \mu \mathrm{M}$. It was very remarkable that $\mathbf{4 e}$, which was found as most effective compound among the newly synthesized compounds, performed an inhibition profile approximately 52 times more effective than used as the reference drug Moclobemide. For the compound $4 \mathbf{e}$ bearing $\mathrm{NO}_{2}$, the presence of electron withdrawing group has a positive effect on MAO enzyme inhibitory activity, especially on MAO-A. 
Table 1. \%Inhibition of the synthesized compounds, Selegiline and Moclobemide against MAO-A and MAO-B.

\begin{tabular}{lllll}
\hline \multirow{2}{*}{ Compounds } & \multicolumn{2}{c}{ MAO-A \% Inhibition } & \multicolumn{2}{c}{ MAO-B \% Inhibition } \\
\cline { 2 - 5 } & $\mathbf{1 0 - 3} \mathbf{M}$ & $\mathbf{1 0 - 4} \mathbf{M}$ & $\mathbf{1 0 - 3} \mathbf{M}$ & $\mathbf{1 0 - 4} \mathbf{M}$ \\
\hline 4a & $58.916 \pm 1.106$ & $44.268 \pm 0.859$ & $39.551 \pm 0.895$ & $28.357 \pm 0.742$ \\
4b & $59.204 \pm 1.001$ & $41.035 \pm 0.788$ & $38.340 \pm 0.986$ & $26.312 \pm 0.836$ \\
4c & $63.578 \pm 1.129$ & $40.654 \pm 0.736$ & $42.735 \pm 0.852$ & $25.769 \pm 0.722$ \\
4d & $55.388 \pm 0.975$ & $43.774 \pm 0.897$ & $40.528 \pm 0.855$ & $20.645 \pm 0.628$ \\
4e & $\mathbf{9 0 . 3 5 4 \pm 1 . 6 5 4}$ & $\mathbf{7 9 . 6 5 9 \pm 1 . 2 4 8}$ & $44.799 \pm 0.997$ & $23.498 \pm 0.709$ \\
Moclobemide & $\mathbf{9 4 . 1 2 1} \pm \mathbf{2 . 7 6 0}$ & $\mathbf{8 2 . 1 4 3 \pm 2 . 6 9 1}$ & - & - \\
Selegiline & $\mathbf{-}$ & - & $\mathbf{9 8 . 2 5 8} \pm \mathbf{1 . 0 5 2}$ & $\mathbf{9 6 . 1 0 7 \pm 1 . 1 6 5}$ \\
\hline
\end{tabular}

Table 2. \% Inhibition and $\mathrm{IC}_{50}$ values of $4 \mathrm{e}$ and Moclobemide against MAO-A.

\begin{tabular}{lcccccccc}
\hline \multirow{2}{*}{ Compound } & \multicolumn{9}{c}{ MAO-A \% Inhibition } & \multicolumn{3}{c}{ IC $_{\mathbf{5 0}}(\boldsymbol{\mu M})$} \\
\cline { 2 - 9 } & $\mathbf{1 0 - 3} \mathbf{M}$ & $\mathbf{1 0 - 4} \mathbf{M}$ & $\mathbf{1 0 - 5} \mathbf{M}$ & $\mathbf{1 0 - 6} \mathbf{M}$ & $\mathbf{1 0}^{-7} \mathbf{M}$ & $\mathbf{1 0}^{-8} \mathbf{M}$ & $\mathbf{1 0}^{-9} \mathbf{M}$ & \\
\hline \multirow{2}{*}{ 4e } & 90.354 & 79.659 & 71.146 & 69.647 & 48.695 & 24.726 & 18.337 & 0.116 \\
& \pm 1.654 & \pm 1.248 & \pm 1.108 & \pm 1.007 & \pm 0.894 & \pm 0.716 & \pm 0.593 & \pm 0.004 \\
\multirow{2}{*}{ Moclobemide } & 94.121 & 82.143 & 60.458 & 36.151 & 22.135 & 18.166 & 14.128 & 6.061 \\
& \pm 2.760 & \pm 2.691 & \pm 2.559 & \pm 1.984 & \pm 1.337 & \pm 0.812 & \pm 0.725 & \pm 0.262 \\
\hline
\end{tabular}

\subsection{In silico ADME prediction}

The computational approach that provides information for drug design greatly helps to reduce cost and time. In this study, Schrödinger QikProp software [25] was used to obtain ADME predictions of all synthesized compounds, further details were given in Table 3. The "Rule of Five" by Lipinski and the "Rule of Three" by Jorgensen enounce the structural properties found in a candidate compound that could be a pharmaceutical compound [26,27]. It was defined that the parameters of the all compounds were in the standard ranges in general and there was not much violation in terms of rules in Table 3. Since the molecules are expected to show activity in the central nervous system (CNS) for antidepressant effect, when the results were analyzed in this respect, it was seen that the predicted CNS activity values of the compounds were between 1 and 2. The value of 1 on this scale represents positive activity in the CNS. In addition, the $\log P$ and $\log$ BB values, which are the guides for the compounds to cross the blood brain barrier, were in the range of 2.613 to 3.368 and (-1.780) to (-0.175), respectively, and were within the recommended limits. Therefore, it can be considered that the synthesized compounds can exceed the blood-brain barrier (BBB), which is very important for CNSrelated drugs. Considering the results of the ADME and BBB permeability studies, the synthesized compounds 4a-e were determined to possess pharmacokinetic profiles that may be appropriate for clinical use.

\subsection{Molecular docking studies}

When the results of the MAO inhibition assay were examined, Compound $4 \mathbf{e}$ was found as the most active derivative (with $\mathrm{IC}_{50}$ value of $0.116 \pm 0.004 \mu \mathrm{M}$ ) in the series against $h \mathrm{MAO}-\mathrm{A}$ enzyme. Therefore, molecular docking studies were carried out to evaluate inhibition capability of Compounds 4e. By using $2.2 \AA$ resolution X-ray crystal structure of $h \mathrm{MAO}-\mathrm{A}$ (PDB ID: 2Z5X) [28] molecular docking studies were performed, and binding modes of Compound $4 \mathbf{e}$ were defined. The docking poses of Compound $4 \mathbf{e}$ were presented in Figures 2 and 3.

Compound 4e was found to bind sufficiently to amino acid residues lining the cavity and was found to be very close to the FAD cofactor (Figure 2). When the molecular docking study of this compound was examined, it was clearly seen that there were three types of interaction including $\Pi-\Pi$, cation- $\Pi$ interactions and formation of hydrogen bond. The п-п interaction was detected between the p-nitrophenyl and the phenyl of Tyr407. Also, there was a cation-ח interaction between the nitrogen atom of nitro group and the phenyl of Try444 (Figure 3). The last interaction was observed in the carbonyl moiety. The carbonyl of Compound 4e formed a hydrogen bond with the amino of Gln215. All these interactions detected explained why Compound $4 \mathbf{e}$ exhibited a stronger inhibition profile the other synthesized compounds. 
Table 3. Parameters of ADME predictions.

\begin{tabular}{lccccc}
\hline Parameters & $\mathbf{4 a}$ & $\mathbf{4 b}$ & Compounds & $\mathbf{4 d}$ & $\mathbf{4 e}$ \\
\hline RB & 7 & 7 & $\mathbf{4}$ & 7 & 8 \\
CNS & 1 & 1 & 7 & 1 & -2 \\
MW & 424.517 & 442.507 & 458.962 & 503.413 & 469.514 \\
DM & 6.483 & 4.547 & 4.618 & 5.006 & 5.362 \\
MV & 1285.76 & 1300.116 & 1321.743 & 1329.202 & 1424.007 \\
DHB & 0 & 0 & 0 & 0 & 0 \\
AHB & 8.25 & 8.25 & 8.25 & 8.25 & 9.25 \\
logP & 2.92 & 3.125 & 3.305 & 3.368 & 2.613 \\
logS & -2.571 & -2.872 & -3.015 & -3.094 & -4.29 \\
Pcaco & 268.557 & 268.522 & 268.535 & 268.541 & 28.536 \\
logBB & -0.313 & -0.222 & -0.183 & -0.175 & -1.78 \\
PMDCK & 221.559 & 362.546 & 425.044 & 447.961 & 19.437 \\
PM & 5 & 5 & 5 & 5 & 6 \\
\%HOA & 87.520 & 88.720 & 89.769 & 77.182 & 68.292 \\
PSA & 87.456 & 87.460 & 87.459 & 87.459 & 131.490 \\
VRF & 0 & 0 & 0 & 1 & 0 \\
VRT & 0 & 0 & 0 & 0 & 0 \\
\hline
\end{tabular}

MW: Molecular weight, DM: Computed dipole moment (recommended value: 1-12.5), RB: Number of rotatable bonds (recommended value: 0-15), MV: Total solventaccessible volume (recommended value: 500-2000), AHB: Estimated number of hydrogen bond acceptors (recommended value: 2-20), DHB: Estimated number of hydrogen bond donors (recommended value: 0-6), PSA: Van der Waals surface area of polar nitrogen and oxygen atoms and carbonyl carbon atoms (recommended value: 7-200), PMDCK: Predicted apparent MDCK cell permeability (recommended value: $<25$ poor, $>500$ great), PM: Number of likely metabolic reactions (recommended value: 1-8) CNS: Predicted central nervous system activity (recommended value: -2 (inactive), +2 (active)), $\%$ HOA: Predicted human oral absorption percent (recommended value: $>80 \%$ is high, $25 \%$ is poor), logS: Predicted aqueous solubility (recommended value: $-6.5-0.5$ ), logP: Predicted octanol/water partition coefficient (recommended value: $-2-6.5$ ), PCaco: Predicted apparent Caco-2 cell permeability (recommended value: $<25$ poor, $>500$ great), logBB: Predicted brain/blood partition coefficient (recommended value: -3 1.2), VRT: Number of violations of Jorgensen's rule of three. The three rules are: $\log S>-5.7$, PCaco $>22 \mathrm{~nm} / \mathrm{s}, \mathrm{PM}<7, \mathrm{VRF}$ : Number of violations of Lipinski's rule of five. The rules are: $M W<500, \log P<5, D H B \leq 5, A H B \leq 10$, Positive PSA value.

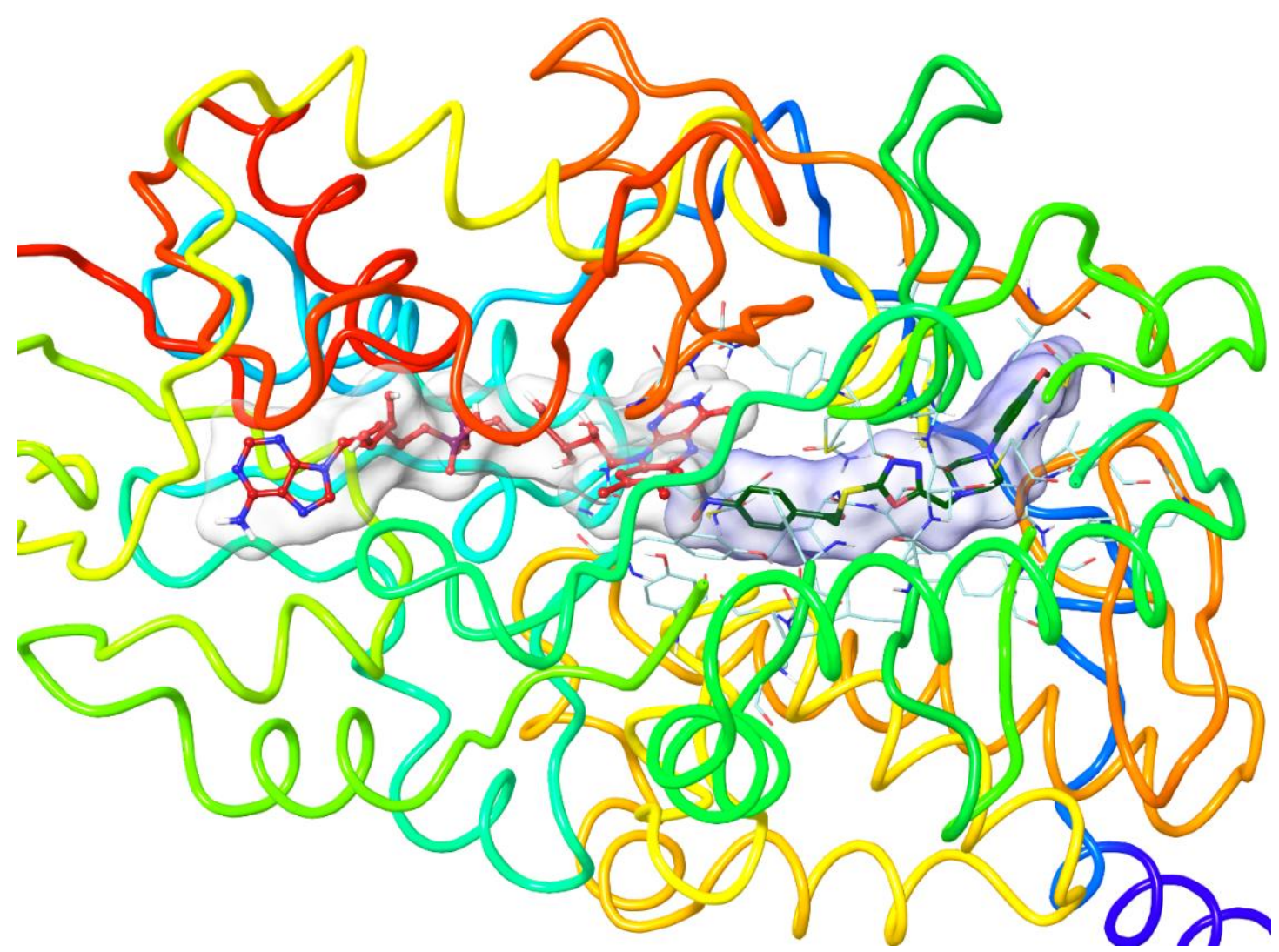

Figure 2. 3D pose of Compound $4 \mathbf{e}$ in the active region of $h \mathrm{MAO}-\mathrm{A}$ (PDB ID: 2Z5X). The significant residues (colored with turquoise) in the active site as tube model and Compound 4e (colored with dark green) are presented. 


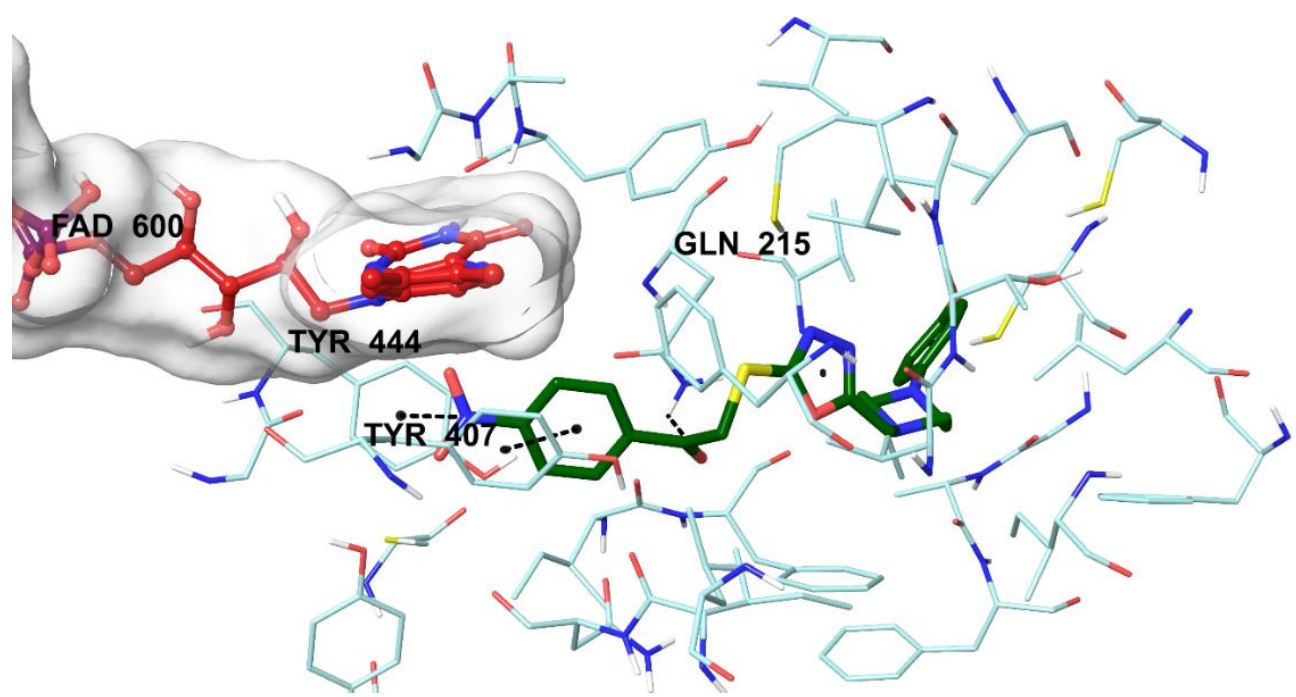

Figure 3. 3D interacting mode of Compound $4 \mathrm{e}$ in the active region of $h \mathrm{MAO}-\mathrm{A}$. The inhibitor and the significant residues in the active site of the hMAO-A are presented by tube model. The FAD molecule (colored with red) is presented by ball and stick model.

\section{CONCLUSION}

It has been reported that heterocyclic structures such as piperazine and oxadiazole are important in terms of biological activity, moreover promising structures in drug design against central nervous system diseases. In this study, a new series 1-(4-substituted phenyl)-2-((5-((4-(4-methoxyphenyl)piperazin-1yl)methyl)-1,3,4-oxadiazol-2-yl)thio)ethan-1-ones was synthesized and characterized and $h$ MAOs inhibition activities were investigated. ADME predictions indicated that all newly synthesized compounds (4a-e) had promising pharmacokinetic properties. Molecular docking studies showed that Compound $4 \mathbf{e}$ sufficiently binds to amino acid residues in the binding cavity of the macromolecule and was very close to the FAD cofactor. Compound 4e, which carries the $\mathrm{NO}_{2}$, has a positive effect on the MAO-A enzyme inhibitory activity compared to halogenated derivatives. In later studies, synthesizing derivatives with electron withdrawing groups such as $\mathrm{NO}_{2}$ may lead to better results in MAO-A inhibitory activity studies. When the $\mathrm{IC}_{50}$ value of the most effective Compound 4e was examined, it was approximately 52 times more active than the reference drug against MAO-A. All these data in the study may prompt pharmaceutical chemists to research similar $h \mathrm{MAO}-\mathrm{A}$ inhibitors that could be valuable for the treatment of depression and anxiety.

\section{MATERIALS AND METHODS}

\subsection{General information}

Each chemicals used in synthesis of compounds were purchased from Sigma-Aldrich Chemicals (Sigma-Aldrich Corp., USA) and Merck Chemicals (Merck KGaA, Germany). Melting points of five synthesized compounds were determined by MP90 digital melting point apparatus (Mettler Toledo, USA) and were uncorrected. The purities of five synthesized compounds were verified by TLC on silica gel 60 F254. HRMS studies were performed on a Shimadzu 8040 LC-MS-MS spectrophotometer (Shimadzu, Japan). ${ }^{1} \mathrm{H}-$ NMR and ${ }^{13} \mathrm{C}-\mathrm{NMR}$ spectra were recorded by a Bruker $300 \mathrm{MHz}$ and $75 \mathrm{MHz}$ digital FT-NMR spectrometer (Bruker Bioscience, USA) in DMSO- $d^{6}$. In the NMR spectra $J$ values (coupling constants) were recorded as Hertz and splitting patterns were symbolized as m: multiplet, $t$ : triplet, $d$ : doublet, s: singlet.

\subsection{Chemistry}

Synthesis of ethyl 2-(4-(4-methoxyphenyl)piperazin-1-yl)acetate (1): $0.04 \quad$ mol $\quad 1-(4-$ methoxyphenyl)piperazin derivative was dissolved in $250 \mathrm{~mL}$ acetone. $0.04 \mathrm{~mol}$ potassium carbonate and ethyl 2-chloroacetate was added and then the reaction mixture was refluxed for 8 hours. The solvent was evaporated with rotary evaporator. Later on the resulting solid was washed by adding water. The mixture was dried after filtration and recrystallized from ethanol to give Compound 1 [29].

Synthesis of 2-(4-(4-methoxyphenyl)piperazin -1-yl)aceto hydrazide (2): 0.03 mol ethyl 2-(4-(4methoxyphenyl)piperazin-1-yl)acetate was dissolved in $250 \mathrm{~mL}$ ethanol. $0.03 \mathrm{~mol}$ hydrazine hydrate dissolved in ethanol, was added slowly and the mixture stirred at room temperature. After the reaction was determined 
to be complete, the solvent was evaporated with a rotary evaporator. Later on the resulting solid was washed by adding water. The mixture was dried after filtration and recrystallized from ethanol to give Compound 2 [29].

Synthesis of 5-[(4-(4-methoxyphenyl)piperazin-1-yl)-1-yl)methyl]-1,3,4-oxadiazole-2-thiol (3): 0.02 mol 2-(4-(4-methoxyphenyl)piperazin-1-yl)-1-yl)aceto hydrazide was dissolved in $250 \mathrm{~mL}$ ethanol. $0.02 \mathrm{~mol}$ potassium hydroxide was dissolved in $80 \mathrm{~mL}$ ethanol with continuous stirring. The second solution was added to first one. $0.02 \mathrm{~mol}$ carbon disulfide was added and then the mixture was refluxed for 5 hours. After the reaction was determined to be complete, dilute $\mathrm{HCl}$ was added to remove the salt form of the compound. Later on the resulting solid was washed by adding water. The mixture was dried after filtration and recrystallized from ethanol to give Compound $3[29,30]$.

General procedure for the synthesis of 1-(substituted phenyl)-2-((5-((4-(4-methoxyphenyl)piperazin-1yl)methyl)-1,3,4-oxadiazol-2-yl)thio)ethan-1-one derivatives $\quad(4 a-e): \quad 10 \quad \mathrm{mmol} 5-[(4-(4-$ methoxyphenyl)piperazin-1-yl))methyl]-1,3,4-oxadiazole-2-thiol derivative was dissolved in $100 \mathrm{~mL}$ acetone. $10 \mathrm{mmol}$ potassium carbonate was added. The indicated phenacyl bromide derivatives were added and stirred for 12 hours at room temperature. After TLC scanning to check the reaction completion, the solvent was evaporated with a rotary evaporator. Later on the resulting solid was washed by adding water. The mixture was dried after filtration and recrystallized from ethanol to give final compounds 4a-e [30].

2-((5-((4-(4-methoxyphenyl)piperazin-1-yl)methyl)-1,3,4-oxadiazol-2-yl)thio)-1-phenylethan-1-one (4a): M.P.: 102.9-104.8 ${ }^{\circ} \mathrm{C}$, Yield: \%77. ${ }^{1} \mathrm{H}-\mathrm{NMR}\left(300 \mathrm{MHz}, \mathrm{DMSO}_{6}\right): \delta=2.56-2.59\left(4 \mathrm{H}, \mathrm{t}\right.$, piperazinyl $\left.\mathrm{CH}_{2}\right), 2.96-2.99(4 \mathrm{H}$, $\mathrm{t}$, piperazinyl $\left.\mathrm{CH}_{2}\right), 3.67\left(3 \mathrm{H}, \mathrm{s}, \mathrm{O}-\mathrm{CH}_{3}\right), 3.84\left(2 \mathrm{H}, \mathrm{s}, \mathrm{N}-\mathrm{CH}_{2}\right), 5.12\left(2 \mathrm{H}, \mathrm{s}, \mathrm{S}-\mathrm{CH}_{2}\right), 6.78-6.87(4 \mathrm{H}, \mathrm{q}$, methoxyphenyl $\mathrm{CH})$, 7.54-7.59 $(2 \mathrm{H}$, t, phenyl $\mathrm{CH})$, 7.67-7.73 $(1 \mathrm{H}, \mathrm{m}$, phenyl $\mathrm{CH}), 8.03-8.06(2 \mathrm{H}, \mathrm{d}, \mathrm{J}=9 \mathrm{~Hz}$, phenyl CH). ${ }^{13} \mathrm{C}-\mathrm{NMR}(75 \mathrm{MHz}$, DMSO-d 6 ): $=49.95,51.30,52.51,55.59,55.62,114.66,117.96,128.94,129.37$, $134.48,135.47,145.68,153.44,164.13,165.06,192.87$. ESI-MS (m/z): [M+H]+: $425.1649(100 \%)$.

1-(4-fluorophenyl)-2-((5-((4-(4-methoxyphenyl)piperazin-1-yl)methyl)-1,3,4-oxadiazol-2-yl)thio)ethan-1-one

(4b): M.P.: $108.3-110.4^{\circ} \mathrm{C}$, Yield: \%89. ${ }^{1} \mathrm{H}-\mathrm{NMR}\left(300 \mathrm{MHz}, \mathrm{DMSO}-\mathrm{d}_{6}\right): \delta=2.55-2.58\left(4 \mathrm{H}, \mathrm{t}\right.$, piperazinyl $\left.\mathrm{CH}_{2}\right)$, 2.96-2.99 $\left(4 \mathrm{H}, \mathrm{t}\right.$, piperazinyl $\left.\mathrm{CH}_{2}\right), 3.67\left(3 \mathrm{H}, \mathrm{s}, \mathrm{O}-\mathrm{CH}_{3}\right), 3.83\left(2 \mathrm{H}, \mathrm{s}, \mathrm{N}-\mathrm{CH}_{2}\right), 5.10\left(2 \mathrm{H}, \mathrm{s}, \mathrm{S}-\mathrm{CH}_{2}\right), 6.78-6.88(4 \mathrm{H}$, q, methoxyphenyl CH), 7.38-7.43 (2H, q, phenyl CH), 8.14-8.16 (2H, m, phenyl CH). ${ }^{13} \mathrm{C}-\mathrm{NMR}(75 \mathrm{MHz}$, DMSO$\left.\mathrm{d}_{6}\right):=49.96,51.31,52.51,55.60,55.63,114.66,116.31,116.60,117.95,132.00,132.12,145.71,153.43,164.05,164.22$, 165.13, 167.57, 191.57. ESI-MS (m/z): [M+H]+: 443.1539 (100\%).

1-(4-chlorophenyl)-2-((5-((4-(4-methoxyphenyl)piperazin-1-yl)methyl)-1,3,4-oxadiazol-2-yl)thio)ethan-1-one (4c): M.P.: 104.8-106.8 ${ }^{\circ} \mathrm{C}$, Yield: \%79. ${ }^{1} \mathrm{H}-\mathrm{NMR}\left(300 \mathrm{MHz}, \mathrm{DMSO}-\mathrm{d}_{6}\right): \delta=2.55-2.58\left(4 \mathrm{H}, \mathrm{t}\right.$, piperazinyl $\left.\mathrm{CH}_{2}\right)$, 2.95-2.98 $\left(4 \mathrm{H}, \mathrm{t}\right.$, piperazinyl $\left.\mathrm{CH}_{2}\right), 3.67\left(3 \mathrm{H}, \mathrm{s}, \mathrm{O}-\mathrm{CH}_{3}\right), 3.83\left(2 \mathrm{H}, \mathrm{s}, \mathrm{N}-\mathrm{CH}_{2}\right), 5.09\left(2 \mathrm{H}, \mathrm{s}, \mathrm{S}-\mathrm{CH}_{2}\right), 6.78-6.88(4 \mathrm{H}$, $\mathrm{m}$, methoxyphenyl $\mathrm{CH}), 7.63-7.66(2 \mathrm{H}, \mathrm{d}, \mathrm{J}=9 \mathrm{~Hz}$, phenyl $\mathrm{CH}), 8.04-8.07(2 \mathrm{H}, \mathrm{d}, \mathrm{J}=9 \mathrm{~Hz}$, phenyl $\mathrm{CH}) .{ }^{13} \mathrm{C}-$ NMR (75 MHz, DMSO-d 6 ): $=49.96,51.32,52.51,55.63,114.67,117.95,129.49,130.86,134.19,139.39,145.70$, 153.43, 163.99, 165.15, 192.06. ESI-MS (m/z): [M+H] $]^{+}: 459.1248(100 \%)$.

1-(4-bromophenyl)-2-((5-((4-(4-methoxyphenyl)piperazin-1-yl)methyl)-1,3,4-oxadiazol-2-yl)thio)ethan-1-one (4d): M.P.: 111.8-112.7०C, Yield: \%81. ${ }^{1} \mathrm{H}-\mathrm{NMR}\left(300 \mathrm{MHz}, \mathrm{DMSO}-\mathrm{d}_{6}\right): \delta=2.55-2.58\left(4 \mathrm{H}, \mathrm{t}\right.$, piperazinyl $\left.\mathrm{CH}_{2}\right)$, 2.95-2.98 $\left(4 \mathrm{H}, \mathrm{t}\right.$, piperazinyl $\left.\mathrm{CH}_{2}\right), 3.67\left(3 \mathrm{H}, \mathrm{s}, \mathrm{O}-\mathrm{CH}_{3}\right), 3.83\left(2 \mathrm{H}, \mathrm{s}, \mathrm{N}-\mathrm{CH}_{2}\right), 5.09\left(2 \mathrm{H}, \mathrm{s}, \mathrm{S}-\mathrm{CH}_{2}\right), 6.78-6.87(4 \mathrm{H}$, $\mathrm{m}$, methoxyphenyl $\mathrm{CH}), 7.77-7.80(2 \mathrm{H}, \mathrm{d}, \mathrm{J}=9 \mathrm{~Hz}$, phenyl $\mathrm{CH}), 7.96,7.99(2 \mathrm{H}, \mathrm{d}, \mathrm{J}=9 \mathrm{~Hz}$, phenyl $\mathrm{CH}) .{ }^{13} \mathrm{C}-$ NMR (75 MHz, DMSO-d 6 ): = 49.95, 51.31, 52.51, 55.59, 55.62, 114.66, 117.95, 128.66, 130.92, 132.45, 134.49, 145.70, 153.43, 163.99, 165.15, 192.28. ESI-MS (m/z): [M+H]+: 503.0757 (100\%).

1-(4-nitrophenyl)-2-((5-((4-(4-methoxyphenyl)piperazin-1-yl)methyl)-1,3,4-oxadiazol-2-yl)thio)ethan-1-one (4e): M.P.: 129.4-131.2 ${ }^{\circ} \mathrm{C}$, Yield: \%82. ${ }^{1} \mathrm{H}-\mathrm{NMR}\left(300 \mathrm{MHz}, \mathrm{DMSO}-\mathrm{d}_{6}\right): \delta=2.55-2.58\left(4 \mathrm{H}, \mathrm{t}\right.$, piperazinyl $\left.\mathrm{CH}_{2}\right)$, 2.95-2.98 (4H, t, piperazinyl $\left.\mathrm{CH}_{2}\right), 3.67\left(3 \mathrm{H}, \mathrm{s}, \mathrm{O}-\mathrm{CH}_{3}\right), 3.84\left(2 \mathrm{H}, \mathrm{s}, \mathrm{N}-\mathrm{CH}_{2}\right), 5.17\left(2 \mathrm{H}, \mathrm{s}, \mathrm{S}-\mathrm{CH}_{2}\right), 6.77-6.87(4 \mathrm{H}$, q, methoxyphenyl CH), 8.25-8.28 (2H, d, J = 9 Hz, phenyl CH), 8.36-8.39 $\left(2 \mathrm{H}, \mathrm{d}, \mathrm{J}=9 \mathrm{~Hz}\right.$, phenyl CH). ${ }^{13} \mathrm{C}-\mathrm{NMR}$ $\left(75 \mathrm{MHz}, \mathrm{DMSO}_{6}\right):=49.95,51.31,52.50,55.61,114.64,117.93,124.44,130.39,140.12,145.69,150.73,153.41$, 163.85, 165.25, 192.41. ESI-MS (m/z): [M+H]+: 470.1495 (100\%).

\subsection{In vitro MAO inhibition assay}

The MAO inhibition test was performed by our research group using the fluorometric method as previously stated, and the $\mathrm{IC}_{50}$ values were also calculated by our research group as previously stated [19-24]. 


\subsection{ADME predictions}

QikProp 4.8 software [25] was used to predict the pharmacokinetic properties of the all synthesized compounds (4a-e), physicochemical parameters were detected with in silico method.

\subsection{Molecular docking studies}

In silico procedure was applied to discover the binding modes of Compound 4e on $h \mathrm{MAO}-\mathrm{A}$ enzyme binding cavity. Pdb file of hMAO-A (PDB ID: 2Z5X) [28], which was crystallized with Harmine, was get from the Protein Data Bank (www.pdb.org). The docking studies was conducted according to procedure of previously published papers by our research group [13, 19-24].

Acknowledgements: Declared none.

Author contributions: Concept - H.U., B.N.S.; Design - H.U, K.B., B.N.S.; Supervision - K.B.; Resources - K.B., H.U., B.N.S., D.O.; Materials - B.N.S., D.O.; Data Collection and/or Processing - H.U., B.N.S., D.O.; Analysis and/or Interpretation - B.N.S., D.O., H.U.; Literature Search - H.U., B.N.S.; Writing - H.U., B.N.S.; Critical Reviews - K.B., H.U., B.N.S., D.O.

Conflict of interest statement: The authors declared no conflict of interest.

\section{Appendix A. Supplementary Material}

Supplementary material related to this article can be accessed at https:// dx.doi.org/10.29228/jrp.99.

\section{REFERENCES}

[1] Youdim MBH, Bakhle YS. Monoamine oxidase: Isoforms and inhibitors in Parkinson's disease and depressive illness. Br J Pharmacol. 2006; 147(SUPPL. 1): S287-S296. [CrossRef]

[2] Carradori S, D'Ascenzio M, De Monte C, Secci D, Yáñez M. Synthesis and Selective Human Monoamine Oxidase B Inhibition of Heterocyclic Hybrids Based on Hydrazine and Thiazole Scaffolds. Arch Pharm (Weinheim). 2013; 346(1): 17-22. [CrossRef]

[3] Kennedy BP, Ziegler MG, Alford M, Hansen LA, Thal LJ, Masliah E. Early and persistent alterations in prefrontal cortex MAO A and B in Alzheimer's disease. J Neural Transm. 2003; 110(7): 789-801. [CrossRef]

[4] Patil PO, Bari SB, Firke SD, Deshmukh PK, Donda ST, Patil DA. A comprehensive review on synthesis and designing aspects of coumarin derivatives as monoamine oxidase inhibitors for depression and Alzheimer's disease. Bioorg Med Chem. 2013; 21(9): 2434-2450. [CrossRef]

[5] Yu PH. Pharmacological and clinical implications of MAO-B inhibitors. Gen Pharmacol: Vasc S. 1994; $25(8)$ : 15271539. [CrossRef]

[6] Evranos-Aksöz B, Yabanoğlu-Çiftçi S, Uçar G, Yelekçi K, Ertan R. Synthesis of some novel hydrazone and 2pyrazoline derivatives: monoamine oxidase inhibitory activities and docking studies. Bioorg Med Chem Lett. 2014; 24(15): 3278-3284. [CrossRef]

[7] DeMaagd G, Philip A. Parkinson's Disease and Its Management: Part 1: Disease Entity, Risk Factors, Pathophysiology, Clinical Presentation, and Diagnosis. P T. 2015; 40(8): 504-532.

[8] Manoharan S, Guillemin GJ, Abiramasundari RS, Essa MM, Akbar M, Akbar MD. The Role of Reactive Oxygen Species in the Pathogenesis of Alzheimer's Disease, Parkinson's Disease, and Huntington's Disease: A Mini Review. Oxid Med Cell Longev. 2016; 8590578; 1-15. [CrossRef]

[9] Mosconi L, Pupi A, De Leon MJ. Brain glucose hypometabolism and oxidative stress in preclinical Alzheimer's disease. Ann N Y Acad Sci. 2008; 1147: 180-195. [CrossRef]

[10] Ankur V, Shweta J, Priyanka J, Prachi J, Nidhi T, Roshni J, Rashi J, Abhishek KJ, Ram KA. Synthesis and Biological Activities of Oxadiazole Derivatives: A Review. Mini Rev Med Chem. 2016; 16(10): 825-845. [CrossRef]

[11] Ke S, Li Z, Qian X. 1,3,4-Oxadiazole-3(2H)-carboxamide derivatives as potential novel class of monoamine oxidase (MAO) inhibitors: Synthesis, evaluation, and role of urea moiety. Bioorg Med Chem. 2008; 16(16): 7565-7572. [CrossRef]

[12] Maccioni E, Alcaro S, Cirilli R, Vigo S, Cardia MC, Sanna ML, Meleddu R, Yanez M, Costa G, Casu L, Matyus P, Distinto S. 3-Acetyl-2,5-diaryl-2,3-dihydro-1,3,4-oxadiazoles: A New Scaffold for the Selective Inhibition of Monoamine Oxidase B. J Med Chem. 2011; 54(18): 6394-6398. [CrossRef] 
[13] Tok F, Uğraş Z, Sağlık BN, Özkay Y, Kaplancıklı ZA, Koçyiğit-Kaymakçığlu B. Novel 2,5-disubstituted-1,3,4oxadiazole derivatives as MAO-B inhibitors: Synthesis, biological evaluation and molecular modeling studies. Bioorg Chem. 2021; 112: 104917. [CrossRef]

[14] Çeçen M, Oh JM, Özdemir Z, Büyüktuncel SE, Uysal M, Abdelgawad MA, Musa A, Gambacorta N, Nicolotti O, Mathew B. Design, Synthesis, and Biological Evaluation of Pyridazinones Containing the (2-Fluorophenyl) Piperazine Moiety as Selective MAO-B Inhibitors. Molecules. 2020; 25(22): 5371. [CrossRef]

[15] Pessoa-Mahana H, Gajardo GR, Araya-Maturana R, Cárcamo JK, Pessoa-Mahana CD. Synthesis of 4-Arylpiperazine Derivatives of Moclobemide: Potential Antidepressants with a Dual Mode of Action. Synth Commun. 2004; 34(14): 2513-2521. [CrossRef]

[16] Sağlık BN, Cebeci O, Acar Çevik U, Osmaniye D, Levent S, Kaya Çavuşoğlu B, Ilgın S, Özkay Y, Kaplancıklı ZA. Design, Synthesis, In Vitro and In Silico Studies of New Thiazolylhydrazine-Piperazine Derivatives as Selective MAO-A Inhibitors. Molecules. 2020; 25(18). [CrossRef]

[17] Gumnick JF, Nemeroff CB. Problems with currently available antidepressants. The Journal of clinical psychiatry. 2000; 61 Suppl 10: 5-15.

[18] Prashanth MK, Revanasiddappa HD, Lokanatha Rai KM, Veeresh B. Synthesis, characterization, antidepressant and antioxidant activity of novel piperamides bearing piperidine and piperazine analogues. Bioorg Med Chem Lett. 2012; 22(23): 7065-7070. [CrossRef]

[19] Can NÖ, Osmaniye D, Levent S, Sağlık BN, Inci B, Ilgın S, Özkay Y, Kaplancıklı ZA. Synthesis of new hydrazone derivatives for MAO enzymes inhibitory activity. Molecules. 2017; 22(8): 1381. [CrossRef]

[20] Can NÖ, Osmaniye D, Levent S, Sağlık BN, Korkut B, Atlı Ö, Özkay Y, Kaplancıklı ZA. Design, synthesis and biological assessment of new thiazolylhydrazine derivatives as selective and reversible hMAO-A inhibitors. Eur J Med Chem. 2018; 144: 68-81. [CrossRef]

[21] Can ÖD, Osmaniye D, Özkay ÜD, Sağlık BN, Levent S, Ilgın S, Baysal M, Özkay Y, Kaplancıklı ZA. MAO enzymes inhibitory activity of new benzimidazole derivatives including hydrazone and propargyl side chains. Eur J Med Chem. 2017; 131: 92-106. [CrossRef]

[22] Ilgın S, Osmaniye D, Levent S, Sağlık BN, Acar Çevik U, Çavuşoğlu BK, Özkay Y, Kaplancıklı ZA. Design and synthesis of new benzothiazole compounds as selective hMAO-B inhibitors. Molecules. 2017; 22(12): 2187. [CrossRef]

[23] Sağlık BN, Çavuşoğlu BK, Osmaniye D, Levent S, Çevik UA, Ilgın S, Özkay Y, Kaplancıklı ZA, Öztürk Y. In vitro and in silico evaluation of new thiazole compounds as monoamine oxidase inhibitors. Bioorg Chem. 2019; 85: 97-108. [CrossRef]

[24] Tok F, Sağlık BN, Özkay Y, Ilgın S, Kaplancıklı ZA, Koçyiğit-Kaymakçığlu B. Synthesis of new hydrazone derivatives and evaluation of their monoamine oxidase inhibitory activity. Bioorg Chem. 2021; 114: 105038. [CrossRef]

[25] QikProp, version 4.8, Schrödinger, LLC, New York, NY, 2016.

[26] Jorgensen WL, Duffy EM. Prediction of drug solubility from structure. Adv Drug Deliver Rev. 2002; 54(3): 355-366. [CrossRef]

[27] Lipinski CA, Lombardo F, Dominy BW, Feeney PJ. Experimental and computational approaches to estimate solubility and permeability in drug discovery and development settings (Reprinted from Advanced Drug Delivery Reviews, vol 23, pg 3-25, 1997). Adv Drug Deliver Rev. 2001; 46(1-3): 3-26. [CrossRef]

[28] Son S-Y, Ma J, Kondou Y, Yoshimura M, Yamashita E, Tsukihara T. Structure of human monoamine oxidase A at 2.2$\AA$ resolution: the control of opening the entry for substrates/inhibitors. Proc Natl Acad Sci U S A. 2008; 105(15): 57395744. [CrossRef]

[29] Kaya B, Özkay Y, Temel HE, Kaplancıklı ZA. Synthesis and biological evaluation of novel piperazine containing hydrazone derivatives. J Chem. 2016: 1-7. [CrossRef]

[30] Kaya B, Kaplancıklı ZA, Yurttaş L, Çiftçi GA. Synthesis and biological evaluation of some new pyrimidine bearing 2, 5-disubstituted 1, 3, 4-oxadiazole derivatives as cytotoxic agents. Turkish J Biochem. 2017; 42(2): 131-137. [CrossRef]

This is an open access article which is publicly available on our journal's website under Institutional Repository at http://dspace.marmara.edu.tr. 